\title{
Het Dravetsyndroom: van paradox tot therapie
}

Het Dravetsyndroom is een ernstige epileptische encefalopathie bij jonge kinderen. Het merendeel van de patiënten heeft een mutatie in het $S C N_{I} A$ gen dat codeert voor een onderdeel van het natriumkanaal $\mathrm{Na}_{\mathrm{V}} \mathrm{I} . \mathrm{I}$. Diermodellen tonen aan dat dergelijke mutaties leiden tot een verminderde functie van inhiberende neuronen, resulterend in verminderde remming van exciterende neuronen. Deze bevinding biedt, naast inzicht in de pathogenese van het Dravetsyndroom, een aangrijpingspunt voor therapie.

\section{Pathofysiologie: een paradox begrepen}

Het Dravetsyndroom, ook wel bekend als Severe Myoclonic Epilepsy in Infancy, is een ernstige genetische vorm van epilepsie. De eerste pathogenetische mutaties in patiënten met het Dravetsyndroom zijn in 200 ontdekt (Claes et al., 200I). Zo'n $80 \%$ van de patiënten met het Dravetsyndroom heeft een heterozygote de novo mutatie (een mutatie in één allel die niet bij de ouders wordt gevonden) in het $\mathrm{SCN}_{1} \mathrm{~A}$ gen. Het gen codeert voor de $\alpha$ I subunit van het $\mathrm{Na}_{\mathrm{V}} \mathrm{I}$.I eiwit een onderdeel van het natriumkanaal dat actiepotentialen in neuronen genereert door instroom van natriumionen. De SCN1A mutaties in het Dravetsyndroom leiden tot een verstoorde transcriptie van het gen met naar verwachting een verminderde expressie en functie van $\mathrm{Na}_{\mathrm{V}} \mathrm{I} . \mathrm{I}$ kanalen tot gevolg. Dit is bevestigd in celbiologische onderzoeken naar de biofysische gevolgen van de SCN1A mutaties, waarbij een verminderde natriuminstroom leidde tot verminderde neuronale exciteerbaarheid (Lossin et al., 2003). Deze bevindingen lijken paradoxaal. Immers, epilepsie wordt geassocieerd met verhoogde neuronale exciteerbaarheid. Studies in transgene muismodellen van het Dravetsyndroom geven een verklaring voor deze paradox: $\mathrm{Na}_{\mathrm{V}} \mathrm{I}$.I kanalen komen voornamelijk tot expressie in inhiberende neuronen; verlies van deze kanalen zal dus leiden tot verminderde exciteerbaarheid van deze neuronen, resulterend in verminderde remming van neuronale circuits (figuur I) (Yu et al., 2006). Een recent onderzoek in geïnduceerde pluripotente stamcellen, verkregen vanuit weefsel van patiënten met Dravetsyndroom, bevestigt deze bevinding: cellen gedifferentieerd tot inhiberende neuronen toonden een verminderde exciteerbaarheid, terwijl cellen gedifferentieerd tot exciterende neuronen normaal functioneerden (Sun et al., 2016).

Recent onderzoek in een muismodel van het Dravetsyndroom toont dat inhiberende neuronen met name vroeg in de ontwikkeling verminderd functioneren, wat mogelijk gedeeltelijk herstelt dankzij een compensatoir verhoogde expressie van andere natriumkanalen (Favero et al., 2018). Deze resultaten suggereren dat de gebrekkige remming een belangrijke rol speelt bij de initiatie van de epilepsie (epileptogenese), waardoor met name vroegtijdige behandeling van groot belang kan zijn.

\section{Nieuwe therapeutische opties}

Veel anti-epileptica hebben een beperkt of zelf averechts effect bij patiënten met het Dravetsyndroom. Anti-epileptica die natriuminstroom remmen, zoals carbamazepine en lamotrigine, kunnen leiden tot verergering van de symptomen. Andere anti-epileptica, zoals topiramaat, valproïnezuur en clobazam, leiden vaak wel tot vermindering van de aanvalsfrequentie. Deze observaties zijn in lijn met de vermoedelijke pathogenese van het Dravetsyndroom: verder verlies van natriuminstroom in inhiberende neuronen kan aanvallen uitlokken. Topiramaat, valprö̈nezuur en benzodiazepines daarentegen versterken de remmende werking van de neurotransmitter GABA, een inhiberende neurotransmitter, waarmee het verlies aan remming in het Dravetsyndroom (gedeeltelijk) wordt opgevangen. Er is echter nog veel winst te behalen in de behandeling van het Dravetsyndroom. Hoewel het stimuleren van GABA-receptoren de epilepsie en andere symptomen kan verbeteren, leidt dergelijke 'tonische' stimulatie tot bijwerkingen en tot mogelijke afname van effectiviteit bij chronische behandeling. Therapieën die juist specifiek aangrijpen op inhiberende neuronen en/of op $\mathrm{Na}_{\mathrm{V}} \mathrm{I}$.I kanalen, waarbij het dynamisch bereik van (inhiberende) neuronen wordt behouden, zijn daarom veelbelovend. Een dergelijke veelbelovende therapeutische optie is cannabidiol, een nietpsychoactief bestanddeel van cannabis. Een recente klinische studie toont een significante vermindering aan in aanvalsfrequentie en -ernst in patiënten met het Dravetsyn- 


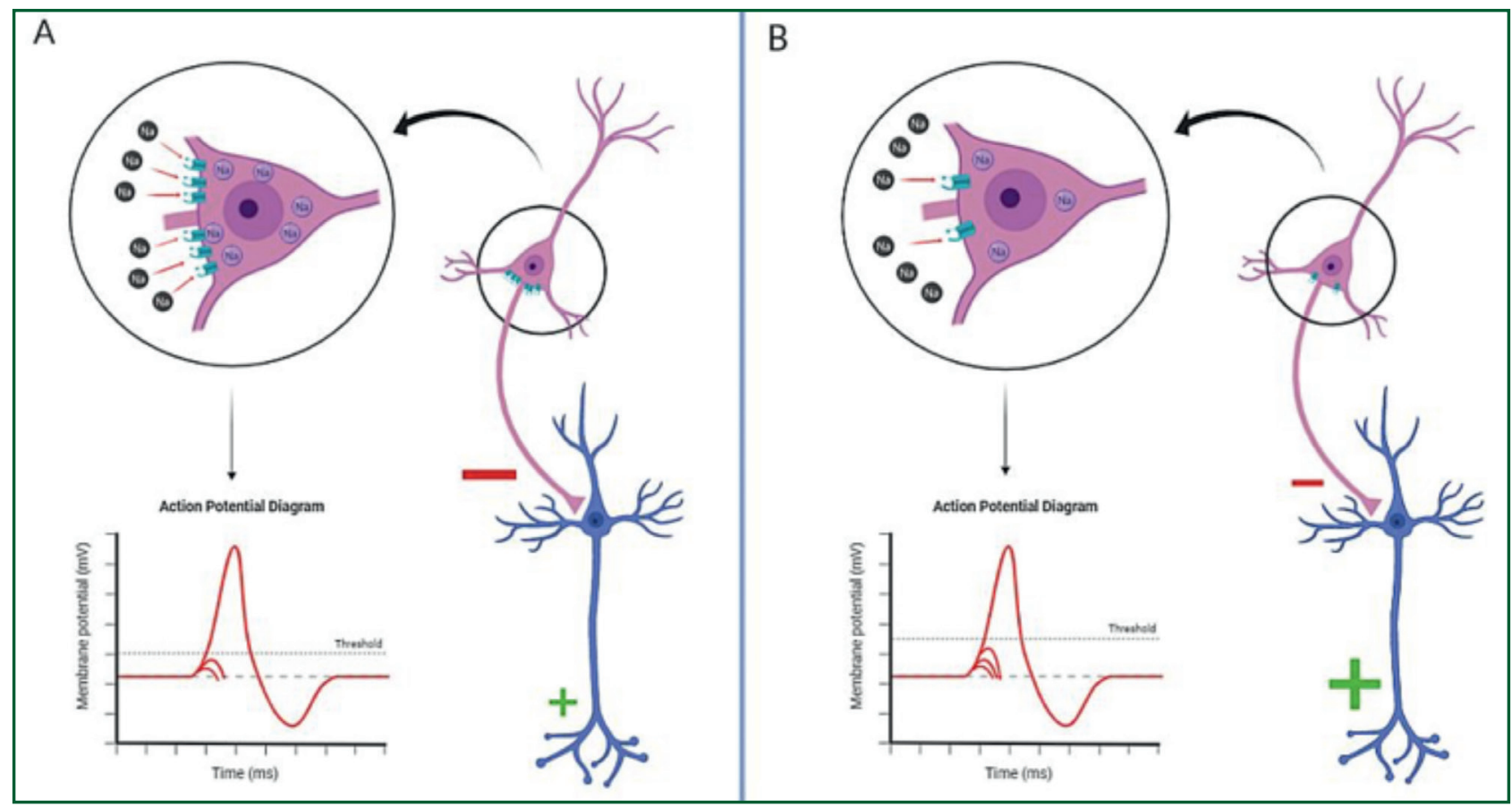

Figuur 1 Verminderde functie van inhiberende neuronen in het Dravetsyndroom. A) Normaal B) Het Dravetsyndroom; het verlies van $\mathrm{Na}_{V^{1.1}}$ natriumkanalen in het inhiberende neuron leidt tot een verminderde natriuminstroom. Hierdoor stijgt de threshold voor het vormen van een actiepotentiaal, met als gevolg dat de remming van het exciterende neuron afneemt. Uiteindelijk leidt dit tot een toegenomen activiteit van exciterende neuronen wat kan resulteren in epileptische aanvallen.

droom (Devinsky et al., 20I7). In een muismodel van het Dravetsyndroom blijkt het effect van cannabidiol geassocieerd te zijn met het herstel van de exciteerbaarheid van inhiberende neuronen in de hippocampus, zonder aan te grijpen op $\mathrm{Na}_{\mathrm{V}} \mathrm{I}$.I, terwijl de exciteerbaarheid van exciterende neuronen juist afneemt (Kaplan et al., 2017). Een andere studie in een muismodel van het Dravetsyndroom toont dat specifieke modulatie van $\mathrm{Na}_{\mathrm{V}}$ I.I kanalen, met behulp van een peptide genaamd Hmra, inactivatie van deze kanalen kan verhinderen. Dit resulteerde in het herstel van de functie van inhiberende neuronen en had geen effect op geïsoleerde, exciterende neuronen, met als gevolg een afname van de aanvalsfrequentie (Richards et al., 20I8).

\section{Conclusie}

Een verminderde functie van inhiberende neuronen, veroorzaakt door verminderde natriuminstroom door verlies van $\mathrm{Na}_{\mathrm{V}} \mathrm{I}$.I kanalen, vormt een aannemelijke verklaring voor het ontstaan van epileptische aanvallen in het Dravetsyndroom. Aangezien onderzoeken in muismodellen tonen dat deze verstoring reeds vroeg in het ziekteproces optreedt, lijkt tijdige behandeling van groot belang. Deze inzichten in de pathogenese van het Dravetsyndroom maken een gerichte zoektocht naar potentiële therapieën mogelijk.

\section{Epilepsie en risico's}

Zeventig procent van de mensen met epilepsie wordt aanvalsvrij. Er zijn dus ook mensen die ondanks medicatie of een andere behandeling nog aanvallen hebben. Die aanvallen kunnen in sommige gevallen risico's met zich meebrengen. Zoals bij de meeste aandoeningen vragen mensen zich af of epilepsie ook levensbedreigend kan zijn. Het antwoord op deze vraag vindt $u$ in de folder 'Epilepsie en risico's'.

Vraagt u de folder aan via e-mail info@epilepsiefonds.nl of telefoon 0306344063 . Het is niet de bedoeling deze folder uit te delen aan patiënten zonder begeleidend gesprek.

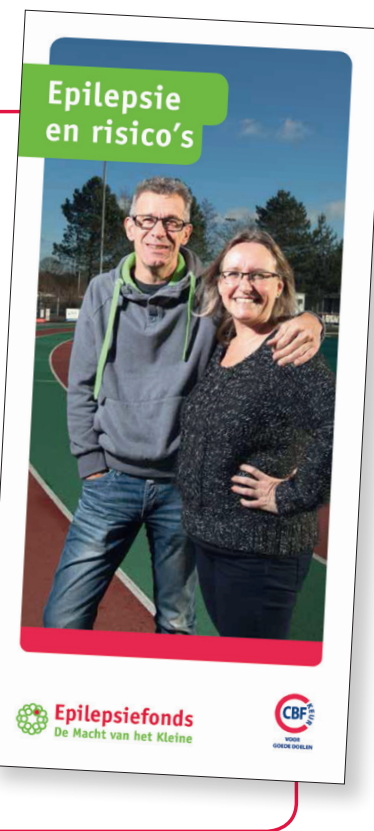

